\title{
Perancangan Aplikasi Manajemen Kepegawaian Berbasis Web Menggunakan Framework Laravel di Pt. Asian Isuzu Casting Center
}

\author{
Ririn Rinasty Br. Sinulingga ${ }^{1}$, Andrew Fernando Pakpahan ${ }^{2}$ \\ ${ }^{1}$ PT. Meeber Teknologi Indonesia \\ ${ }^{2}$ Fakultas Teknologi Informasi Universitas Advent Indonesia \\ Email: rinastyririn@gmail.com, *2andrew@unai.edu,
}

\begin{abstract}
Abstrak
Sistem Informasi Kepegawaian adalah satu wadah manajemen data karyawan yang dapat dikelola dengan mudah dan akurat menggunakan sistem informasi. Manajemen data karyawan di PT. Asian Isuzu Casting Center selama ini masih menggunakan Microsoft Excel. Adapun kegunaan yang diharapkan dari penelitian ini adalah: 1) Meningkatkan kinerja karyawan dalam melaksanakan tugas. 2) Menghemat waktu dalam pencarian data yang sudah disimpan. 3) Mempermudah karyawan mengelola data di mana saja dan kapan saja 4) Mengurangi kerugian yang tidak terduga karena data yang tidak teratur. Metodologi yang digunakan dalam penelitian ini adalah metode SDLC (System Development Life Cycle) yang terdiri dari lima tahap antara lain, (1) Analisa Kebutuhan, (2) Desain Sistem, (3) Coding, dan (4) Pengujian. Tujuan penelitian yang diharapkan dapat menghasilkan sistem informasi Sistem Informasi Kepegawaian di PT. Asian Isuzu Casting Center. Dari penelitian yang telah dilakukan, penulis, penulis menyimpulkan bahwa, (1) Sistem informasi yang dirancang dan komponen berjalan dengan baik. (2) Sistem ini dapat membantu mempermudah dalam pembuatan laporan data karyawan di PT. AICC. (3) Sistem informasi ini dapat membuat laporan data cuti dan data izin.
\end{abstract}

Kata Kunci: Sistem Informasi, Sistem Informasi Kepegawaian

\section{A Design of Web-based Employee Management System using Laravel Framework in PT. Asian Isuzu Casting Center}

\section{Abstract}

The Employee Management System is an employee data management container that can be managed with accurate information systems. Employee data management at PT. Asian Isuzu Casting Center still uses Microsoft Excel. The expected usefulness of this study are: 1) Improving employee performance in carrying out tasks. 2) Saving time in searching for stored data. 3) making it more easily for employees to manage data anywhere and anytime 4) Reducing unexpected losses due to irregular data. The methodology used in this study is the SDLC (System Development Life Cycle) method which consists of five stages, among others, (1) Needs Analysis, (2) System Design, (3) Coding, (4) Testing and (5) Implementation. The research objectives are expected to produce an Employee Management System information system at PT. Asian Isuz Casting Center. From the research that has been done, the authors, the authors conclude that, (1) Information systems are made and components are running well. (2) This system can help facilitate the creation of employee data reports at PT. AICC. (3) This information system can create data reports and data permissions.

Keywords: Information System, Employee Information System 


\section{Pendahuluan}

Perkembangan zaman sekarang ini didukung oleh teknologi dan informasi yang semakin pesat, teknologi memberikan manfaat yang sangat besar bagi masyarakat, baik di dunia usaha maupun di dunia pendidikan. Saat ini teknologi menjadi salah satu kebutuhan manusia yang sangat penting, karena dapat membantu berbagai kegiatan, ditambah dengan teknologi informasi yang semakin berperan di dalam dunia perkerjaan. Dalam hal ini berkaitan dengan pekerjaan manusia yang dilakukan dengan manual akan lebih semakin efektif dan efisien jika dilakukan dengan komputer. Kemajuan teknologi yang semakin maju membantu mempermudah pengguna dalam meningkatkan pekerjaan dengan menggunakan komputer, pekerjaan akan menghemat waktu, biaya, tenaga dan mempermudah untuk memperoleh informasi. Menggunakan teknologi informasi yang tepat akan menghasilkan data informasi yang tepat dan akurat sesuai dengan kebutuhan, sehingga dapat menjamin kualitas informasi yang disajikan dan dapat mengambil keputusan dengan cepat. Dengan menggunakan teknologi perusahaan akan mampu bersaing dengan perusahaan lain karena peranan teknologi informasi tidak diragukan lagi dan dukungannya mampu membuat perusahaan memiliki kemampuan kompetitif.

Sistem Informasi Kepegawaian adalah satu wadah manajemen data karyawan yang dapat dikelola dengan mudah dan akurat menggunakan sistem informasi. Menggunakan sistem informasi dalam manajemen data karyawan sangat berguna untuk memajukan kinerja perusahaan. Kegiatan mengelola data karyawan seperti jumlah karyawan yang melamar, karyawan yang diterima dan data persyaratan karyawan yang telah lulus akan lebih menjamin ketepatan data dengan menggunakan sistem informasi. Sistem informasi manajemen data karyawan dibutuhkan oleh semua perusahaan. Salah satunya adalah PT. Asian Isuzu Center Casting. Perusahaan ini adalah perusahaan Jepang yang berada di KIIC (Karawang International Industrial City), perusahaan ini bergerak di bidang manufaktur. Perusahaan ini memiliki lebih dari 800 pegawai baik di bagian administrasi maupun di bagian produksi.

Manajemen data karyawan di PT. AICC masih menggunakan Microsoft Excel. Kegiatan manajemen data di perusahaan dilakukan dengan beberapa tahapan penyimpanan, yang pertama adalah karyawan mengisi data di kertas dan akan dimasukkan ke dalam Microsoft Excel. Sistem manajemen menggunakan Microsoft Excel masih memiliki banyak kekurangan, terutama dalam mencari data dan menampilkan data yang sudah disimpan. Ketika mencari data akan menampilkan semua data. Selanjutnya dalam menyimpan data memiliki kendala yaitu terjadinya redundant data atau proses manajemen data yang sama, masalah yang lain juga dapat terjadi di mana akan menyebabkan kerugian yang berakibat bari perusahaan maupun karyawan. Untuk menghindari masalah yang ada, menggunakan teknologi informasi akan membantu pihak HRD dalam penyimpanan data di mana data akan disimpan di dalam satu sistem, data dapat dibuka melalui perangkat mana saja yang terhubung dengan internet di PT. AICC. Adapun kegunaan yang diharapkan dari penelitian ini adalah: 1) Meningkatkan kinerja karyawan dalam melaksanakan tugas. 2) Menghemat waktu dalam pencarian data yang sudah disimpan. 3) Mempermudah karyawan mengelola data di mana saja dan kapan saja 4) Mengurangi kerugian yang tidak terduga karena data yang tidak teratur.

Maksud penelitian ini adalah merancang sebuah suatu Sistem Informasi Kepegawaian untuk HRD dalam mengelola data karyawan khusus untuk PT. AICC. Tujuan penelitian yang diharapkan dapat dicapai adalah menghasilkan sistem informasi yang dapat digunakan di perusahaan PT. AICC dan dapat membantu pekerjaan karyawan dalam mengelola data karyawan.

\section{Tinjauan Pustaka}

Sistem dan informasi memiliki makna yang berbeda namun bila sistem dan informasi digabungkan maka menjadi alat yang membantu dan akan berguna seperti yang telah diteliti oleh para ahli. Berikut penjelasan dasar teori sistem dan informasi. Menurut penulis di [1], menerangkan bahwa sistem informasi merupakan suatu sistem di dalam suatu organisasi untuk mempertemukan kebutuhan pengolahan transaksi harian, mendukung operasi, bersifat manajerial dan kegiatan strategi dari suatu organisasi dan 
Perancangan Aplikasi Manajemen Kepegawaian Berbasis Web Menggunakan Framework Laravel di Pt. Asian Isuzu Casting Center

menyediakan pihak luar tertentu dengan laporan-laporan yang dibutuhkan. Menurut penulis di [2] sistem informasi terdiri dari sejumlah komponen (manusia, komputer, teknologi informasi, dan prosedur kerja). Sistem informasi juga memproses data menjadi informasi yang dikembangkan untuk mencapai suatu sasaran atau tujuan.

Menurut para penulis di [3], mengemukakan database adalah suatu media untuk menyimpan data agar dapat diakses dengan mudah dan cepat. Menurut [4], Database merupakan kumpulan koleksi data yang saling terhubung secara logika dan sebuah deskripsi dari data tersebut, dibentuk untuk mendapatkan solusi informasi pada sebuah perusahaan

Berdasarkan ringkasan basis data adalah sebuah wadah penyimpanan yang dapat diakses dan mudah ditemukan dan dapat digunakan oleh banyak pengguna sekaligus sesuai dengan kebutuhan.

\section{Penelitian Terdahulu}

Beberapa peneliti terdahulu yang relevan telah membantu penelitian ini, sebagai referensi dalam pemilihan topik penelitian. Di antaranya yaitu:

a. Penelitian yang dilakukan oleh Bororing, dkk. [5], menemukan bahwa data dan informasi administrasi perlu disiapkan sebelum diproses di aplikasi sehingga pelayanan dapat berjalan dengan baik. Pegawai tidak perlu lagi simpang siur untuk mencari informasi yang dibutuhkan karena sudah dipublikasi di halaman web. Sementara untuk pengolahan menggunakan aplikasi komputer sebagai pembantu dan melibatkan atasan sebagai pengambil keputusan. Aplikasi kepegawaian digunakan sebagai alat bantu untuk proses dan hasil dari pengolahan administrasi.

b. Penelitian yang dilakukan oleh Rachmanaiah, dkk. [6], menemukan bahwa pengurusan administrasi kepegawaian mempunyai prosedur birokrasi yang cukup kompleks dan waktu yang cukup lama, serta sering kesulitan dalam pemantauannya. Pada saat ditangani secara manual, tidak dapat menyediakan kebutuhan informasi yang cepat, tepat dan akurat. Pada saat dibutuhkan, informasi yang diberikan membutuhkan waktu yang lama sehingga menimbulkan konsekuensi yang merugikan secara finansial.

c. Penelitian yang dilakukan oleh Abdullah [7] Dari penelitian tersebut dapat ditarik kesimpulan dengan menggunakan sistem berbasis web untuk penyimpanan data karyawan dapat diakses dari mana saja dan akan lebih memudahkan untuk pengelolaan data. Latar belakang perancangan sistem ini adalah proses pengolahan data kepegawaian di lingkungan sekretariat kabupaten Aceh Utara masih menggunakan Microsoft Excel sehingga masih kurang efisien cepat dan tepat dalam pengolahan data pegawai. Metode yang dilakukan adalah Metode studi literatur, metode observasi dan wawancara. Perancangan sistem merupakan bagian yang paling penting dalam pengembangan suatu sistem informasi dan salah satu komponen sistem yang dapat dijadikan tolak ukur keberhasilan sistem adalah keluaran. Hasil dari penelitian tersebut adalah mendapatkan hasil yang akurat dalam mengelola data kepegawaian.

d. Penelitian yang dilakukan oleh Purwanto [8], merancang suatu sistem administrasi kepegawaian berbasis web untuk input data kepegawaian, input saldo cuti, input training dan input peringatan yang dilakukan oleh HRD. Dengan menggunakan sistem yang dibangun data dan dokumen menjadi tidak tercecer dan menghindari terjadinya double input. Sehingga sistem yang dibangun membantu keakuratan dalam pembuatan data dan data yang ada dapat dibagi langsung ke sistem yang dimiliki pegawai tanpa harus menggunakan kertas.

\section{Analisa dan Perancangan Sistem}

\section{Metode Penelitian}

Metode yang digunakan penulis untuk penelitian perancangan sistem adalah metodologi yang umun digunakan yaitu: SDLC (System Development Life Cycle) metodologi yang digunakan ini terbagi menjadi beberapa bagian yang sudah diuji oleh beberapa para ahli sebagai berikut: 


\section{Analisa Kebutuhan}

Pada tahapan ini penulis akan menganalisis permasalahan dan kebutuhan yang diperlukan untuk perancangan sistem. Tahapan hanya melibatkan Human Resources Development (HRD), sistem hanya akan digunakan oleh pihak HRD maka masukan hanya berasal dari mereka mulai dari fitur yang akan dibangun hingga data yang akan dimasukkan ke dalam sistem yang akan dibangun.

2. Desain Sistem

Pada tahapan ini yang akan dilakukan adalah mendesain sistem dengan menggunakan Use Case Diagram, Activity Diagram, Sequence Diagram, Class Diagram dan tahap desain tampilan.

\section{Coding}

Pada tahapan ini penulis menggunakan kode pemrograman untuk menerjemahkan rencana dan analisis sistem ke dalam ke dalam bahasa pemrograman tertentu yang dimengerti oleh komputer. Code yang dibentuk akan menghasilkan suatu sistem informasi yang sesuai dengan perintah perancangan.

\section{Pengujian}

Sistem yang sudah dibangun akan dilakukan pengujian, apakah sistem sudah sesuai dengan kriteria yang dimaksud oleh pihak HRD.

\section{Latar Belakang Objek Penelitian}

Sistem informasi manajemen data karyawan adalah aspek yang penting bagi perusahaan. Karena dengan dukungan sistem sebuah perusahaan akan menjamin keakuratan manajemen data karyawan. PT. AICC (PT. AICC) adalah sebuah perusahaan yang bergerak di bidang manufaktur. Perusahaan ini adalah perusahaan Jepang yang maju dan memiliki ratusan karyawan.

Sejarah perusahaan PT. AICC bermula pada April tahun 1997, PT.AICC merupakan perusahaan PMA (Penanam Modal Asing) Jepang yang bergerak di bidang manufaktur pengecoran logam. Awal berdirinya perusahaan bernama PT. AICC Company. Pada bulan Juni tahun 2004 nama perusahaan berubah menjadi PT. AICC dikarenakan struktur kepemilikan saham berubah.

PT. AICC berlokasi di Kawasan Industri KIIC Karawang dengan jumlah karyawan pada tahun 2014 sekitar 569 orang, terdiri dari karyawan kontrak dan tetap. Luas tanah sekitar 78,854 m2 dan luas bangunan 32,295 m2. Kepemilikan modal seluruhnya (100\%) sebagai perusahaan PMA (Penanam Modal Asing) Jepang yang dipegang oleh 3 (tiga) pemegang saham yaitu, I Metal Technology Co., Ltd., Isuzu Motor Asia Limited, Isuzu Motor Limited.

\section{Proses Bisnis Lama}

Proses bisnis yang sementara berjalan adalah mengisi data karyawan di dalam Microsoft Excel (Gambar 1). 


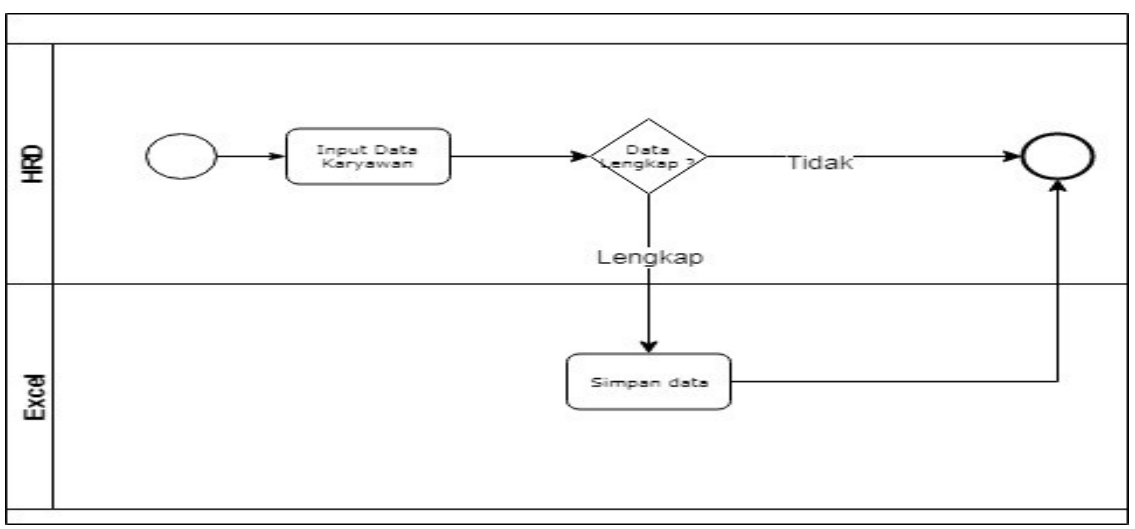

Gambar 1 Proses Bisnis Yang Terjadi Saat ini - Penyimpanan Data

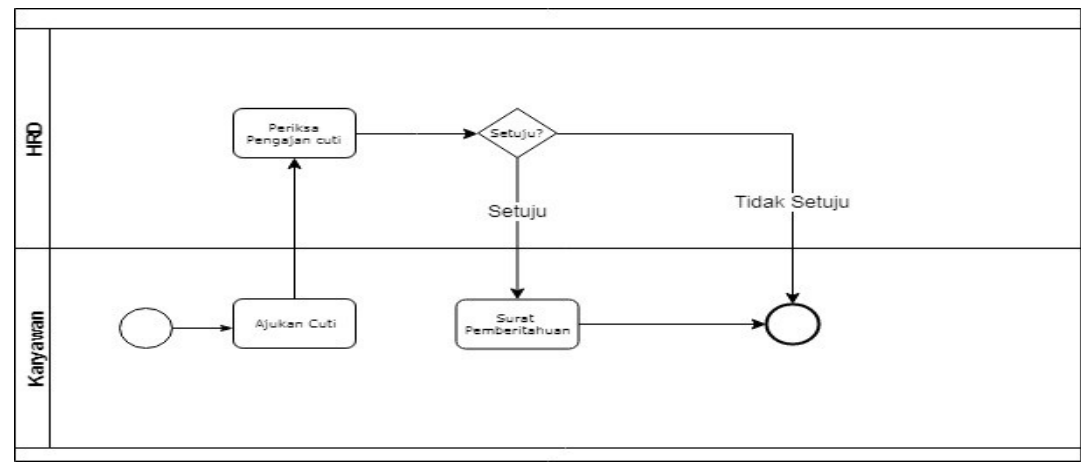

Gambar 2 Proses Bisnis Yang Terjadi Saat Ini - Pengajuan Cuti

Bagi karyawan yang akan melakukan administrasi kepegawaian (seperti: cuti, resign, dsb) perlu mengajukan terlebih dahulu dan keputusan akan diberikan dengan surat pemberitahuan setelah data diperiksa dan disimpan di file Ms. Excel (Gambar 2).

\section{Proses Bisnis Baru}

Di dalam proses bisnis yang baru, aplikasi Excel akan digantikan dengan aplikasi yang dikembangkan di dalam penelitian ini. Data karyawan akan dikelola di dalam aplikasi, mulai dari pembuatan data karyawan, pengajuan resign, cuti, izin dan kontrak. Kemudian aplikasi yang dikembangkan dapat menghasilkan laporan data karyawan yang dapat dilihat oleh pihak yang berwenang. Bagian berikut dari tulisan ini akan menjelaskan mengenai sistem baru yang dikembangkan.

\section{Perancangan Sistem Baru}

Perancangan sistem dibangun dengan melakukan analisa kebutuhan yang dapat membantu pembangunan sebuah sistem baru maka diperlukan persiapan untuk merancang sistem yang dapat memecahkan masalah dalam perancangan sistem manajemen data karyawan.

Gambar 3 memperlihatkan Use Case Diagram dalam aplikasi manajemen data karyawan yang dirancang hanya memiliki satu aktor yaitu admin. Hanya admin yang mempunyai hak akses dalam pengelolaan data karyawan yang meliputi input, update, delete dan pelaporan data. 


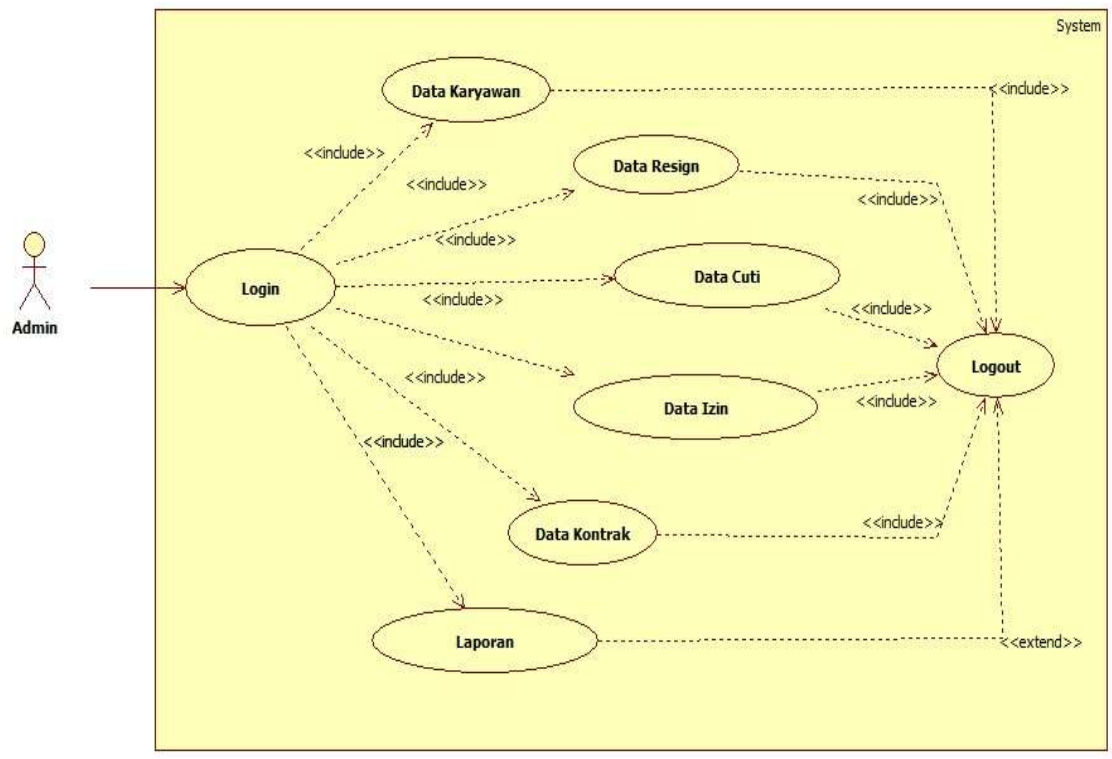

Gambar 3 Use Case Diagram aplikasi yang dirancang

Adapun aktor dan penjelasan hubungan yang terjadi serta yang terlibat dan berhubungan dalam sistem ini adalah sebagai berikut:

1. Pertama admin harus login dulu, sehingga dapat melihat semua data karyawan dan selanjutnya dapat melakukan semua

2. Admin dapat melakukan pengelolaan data karyawan seperti menambah, mengubah dan menghapus data.

3. Admin dapat melakukan pengelolaan data resign seperti menambah, mengubah dan menghapus data.

4. Admin dapat melakukan pengelolaan data cuti seperti menambah, mengubah dan menghapus data.

5. Admin dapat melakukan pengelolaan data izin seperti menambah, mengubah dan menghapus data.

6. Admin dapat melakukan pengelolaan data kontrak kerja karyawan seperti menambah, mengubah dan menghapus data.

7. Laporan data merupakan list data bagi karyawan yang melakukan cuti.

8. Laporan data merupakan list data bagi karyawan yang melakukan izin

9. Logout, digunakan untuk keluar dari aplikasi yang digunakan.

Pada Gambar 4 dapat dilihat Class Diagram yang digunakan di sistem yang dibangun. Ada beberapa class yang digunakan yaitu: Karyawan, Departemen , Izin, Cuti, Jabatan, Kontrak, Pendidikan. Masingmasing class merupakan model yang digunakan untuk melambangkan tabel yang digunakan di dalam database dan mempunyai data yang berkaitan dengan nama kelasnya. Sehingga dapat mudah dimengerti dan dikembangkan apabila dibutuhkan di kemudian hari. 


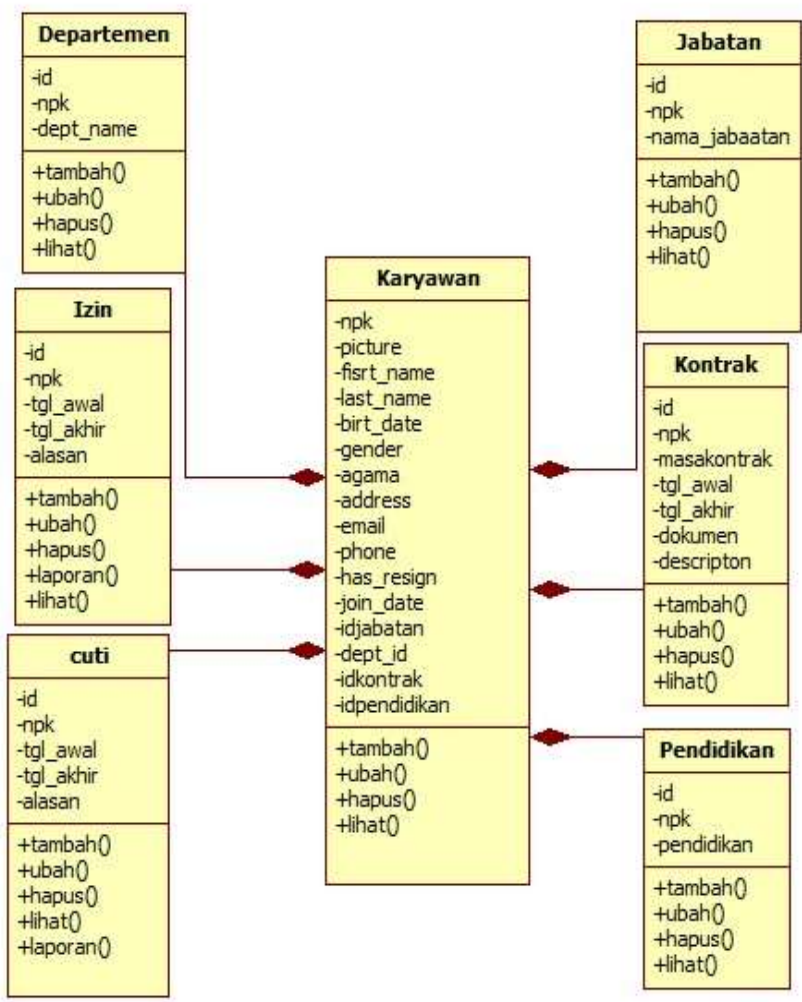

Gambar 4 Class Diagram aplikasi yang dirancang

\section{Perancangan Desain Antar Muka Sistem}

Rancangan desain sistem dibuat bertujuan sebagai acuan dalam perancangan sebuah sistem. Berikut desain sistem yang akan direncanakan: Pada Gambar 5 dapat dilihat rancangan antar muka untuk halaman login dan halaman dashboard awal ketika login berhasil dilakukan.

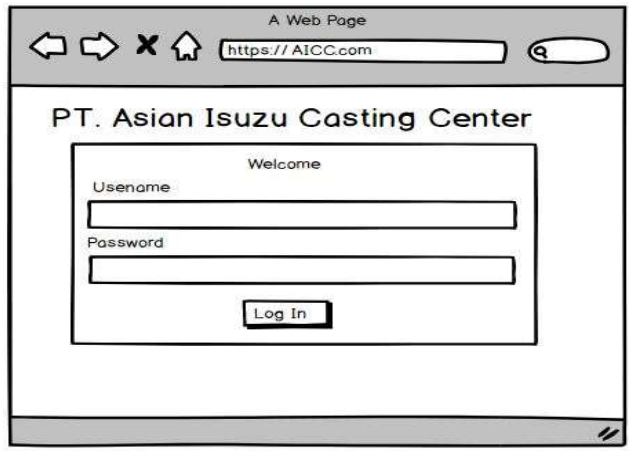

(a)

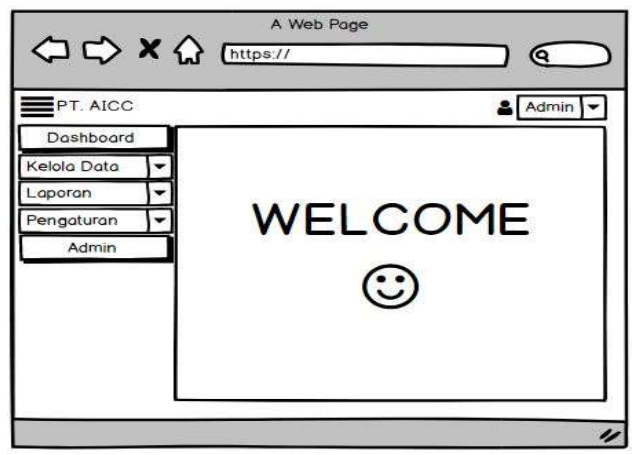

(b)

Gambar 5 Rancangan tampilan aplikasi (a) Halaman Login (b) Halaman Awal

Pada Gambar 6 dapat dilihat rancangan antar muka untuk menampilkan dan juga menambah data karyawan. Pada Gambar 7 dapat dilihat rancangan antar muka untuk menampilkan dan juga menambah data karyawan yang resign. Pada Gambar 8 dapat dilihat rancangan antar muka yang menampilkan pengaturan departemen dan juga jabatan. Selain dari gambar-gambar yang sudah ditampilkan di tulisan 
ini, masih banyak rancangan antar muka yang sudah dibuat. Namun, karena keterbatasan tempat maka hanya sebagian rancangan yang ditampilkan dalam gambar yang ada di tulisan ini.

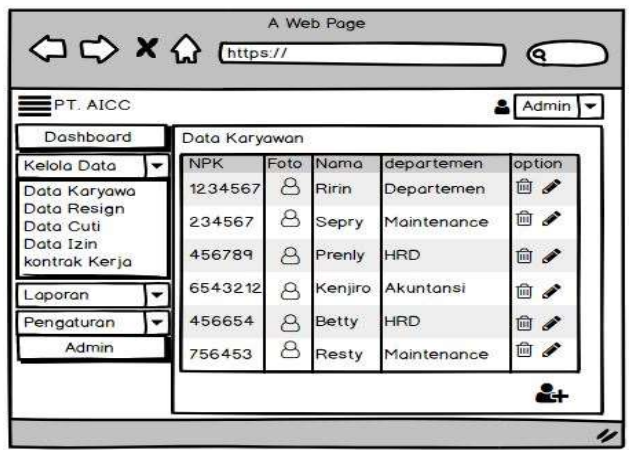

(a)

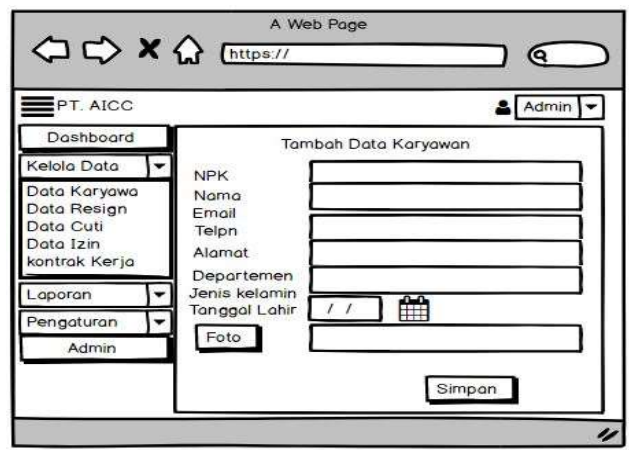

(b)

Gambar 6 Rancangan tampilan aplikasi (a) Halaman data karyawan (b) Halaman tambah data karyawan

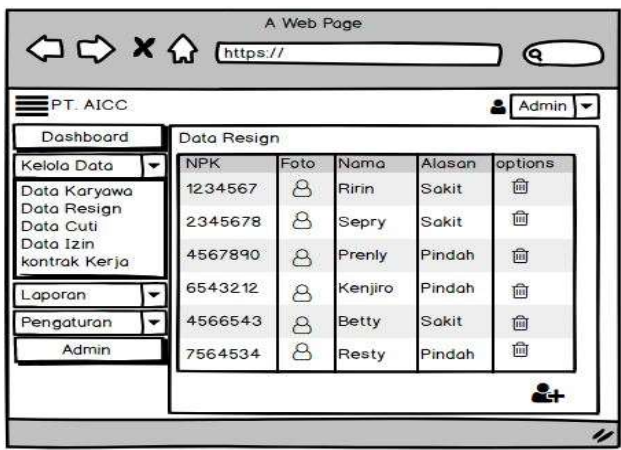

(a)

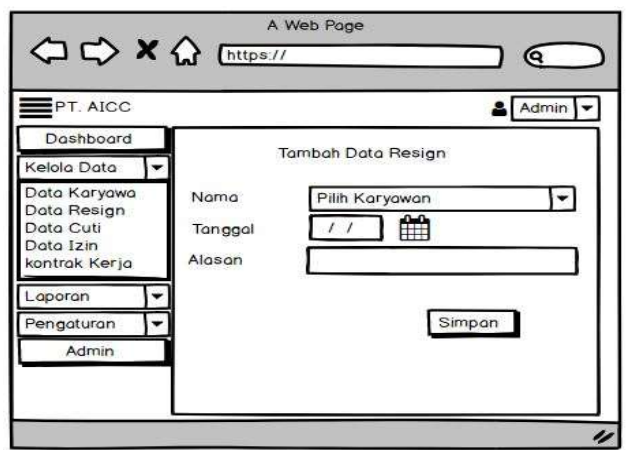

(b)

Gambar 7 Rancangan tampilan aplikasi (a) Halaman data resign (b) Halaman tambah data resign

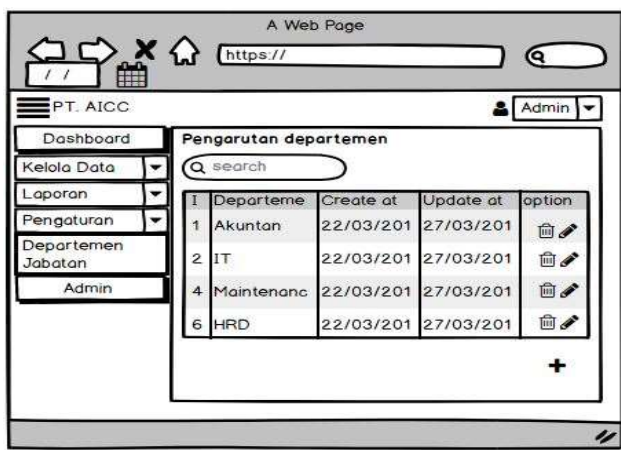

(a)

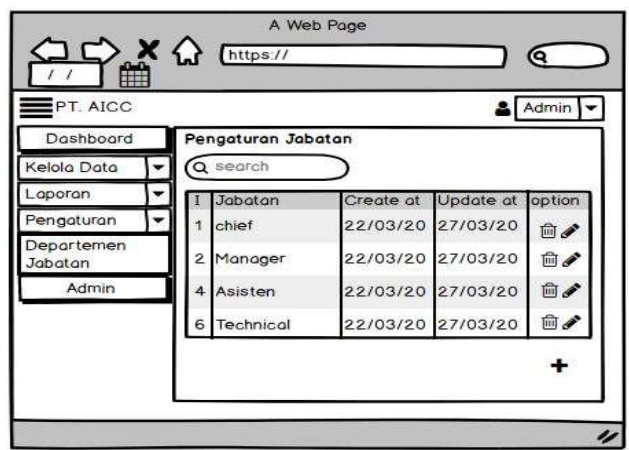

(b)

Gambar 8 Rancangan tampilan aplikasi (a) Halaman pengaturan departemen (b) Halaman pengaturan jabatan 


\section{Hasil dan Pembahasan}

Perangkat Lunak yang digunakan untuk membangun sistem informasi perancangan penyimpanan data karyawan yang terdiri dari beberapa komponen program. Komponen-komponen tersebut membantu agar penyimpanan data dapat berjalan dengan baik. Adapun komponen tersebut antara lain:

1. Sistem Operasi Windows 7

2. XAMPP V7.1.4

3. Phpmyadmin

4. MySQL

5. Apache

6. Laravel V5.4

7. Composer

8. Atom

9. Google Chrome

\section{Hasil perancangan}

Dari hasil analisa proses bisnis yang lama, analisa kebutuhan dan perancangan yang dilakukan maka aplikasi manajemen kepegawaian sudah diselesaikan dengan tampilan yang dapat dilihat di bawah ini. Karena keterbatasan tempat, maka tidak semua bagian dari aplikasi yang sudah berjalan dapat ditampilkan di tulisan ini.

Gambar 9 menampilkan hasil rancangan halaman login dan tampilan halaman dashboard.

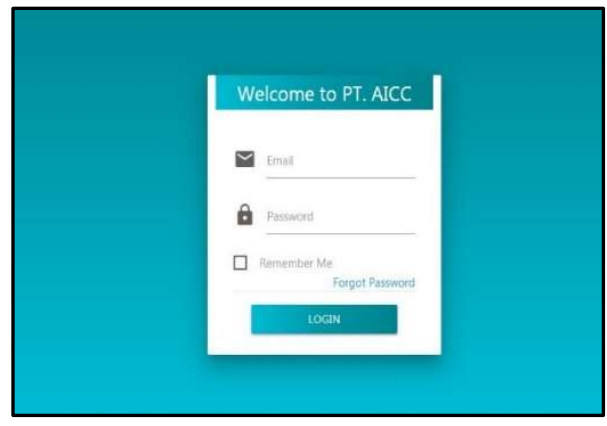

(a)

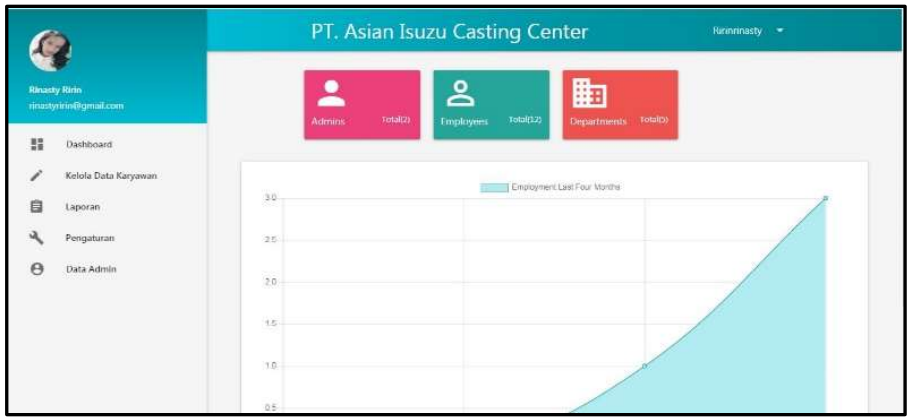

(b)

Gambar 9 Hasil rancangan aplikasi (a) Halaman login (b) Halaman dashboard

Gambar 10-12 menampilkan hasil akhir dari aplikasi yang dirancang. Dapat dilihat tampilan halaman untuk data karyawan, halaman input data karyawan baru, tampilan halaman karyawan detil dan juga tampilan untuk print data karyawan. Aplikasi yang dihasilkan merupakan hasil penuangan rancangan yang sudah diberikan di bagian sebelumnya dari tulisan ini. 


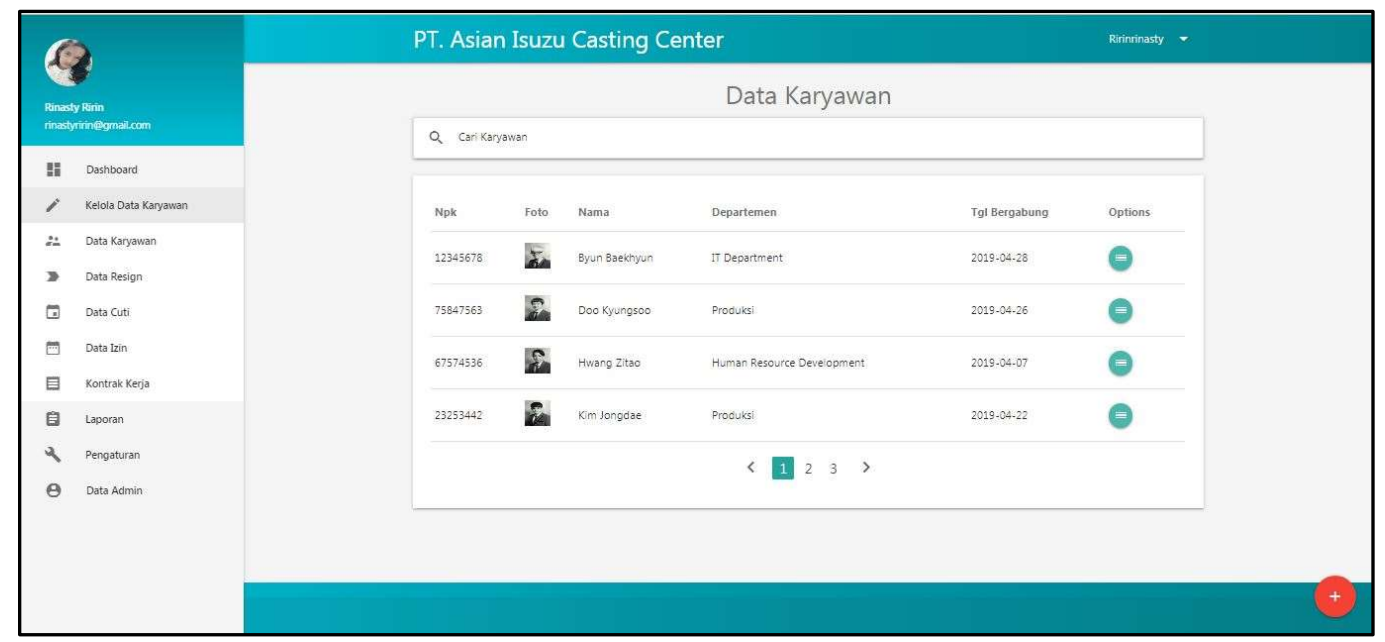

Gambar 10 Tampilan halaman data karyawan

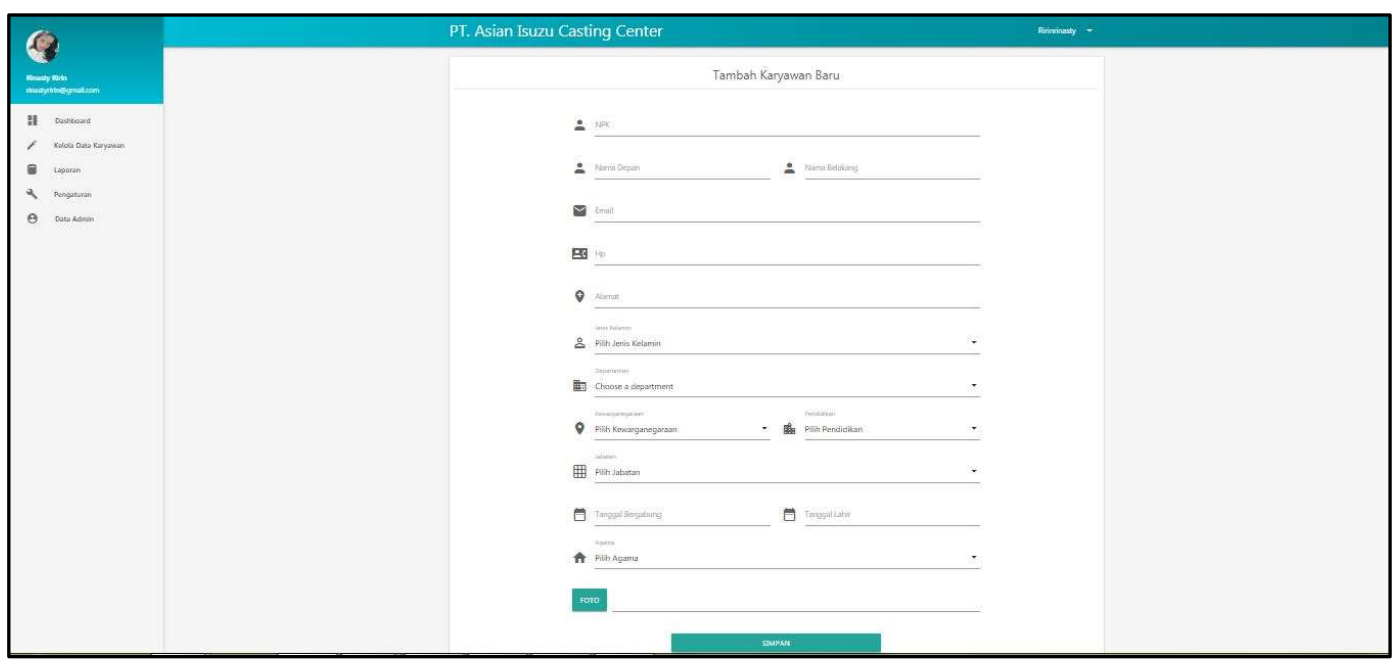

Gambar 11 Tampilan halaman tambah karyawan baru

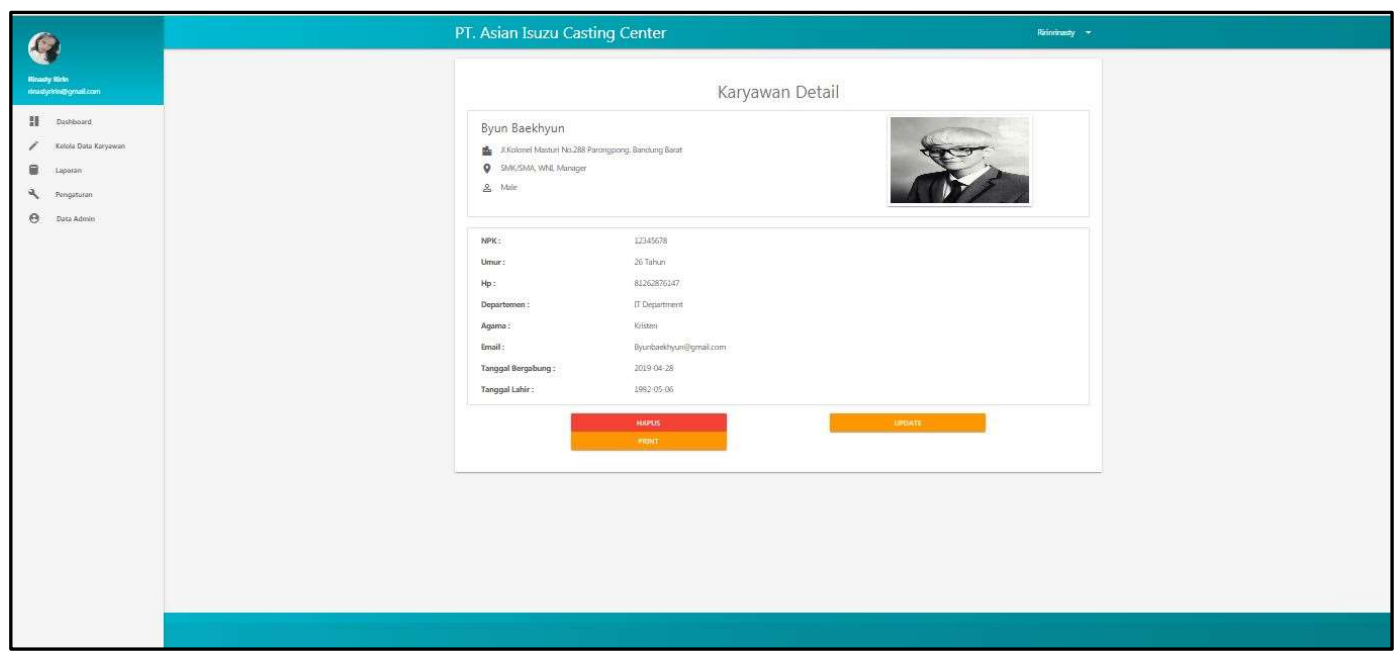

Gambar 12 Rancangan halaman karyawan detil 


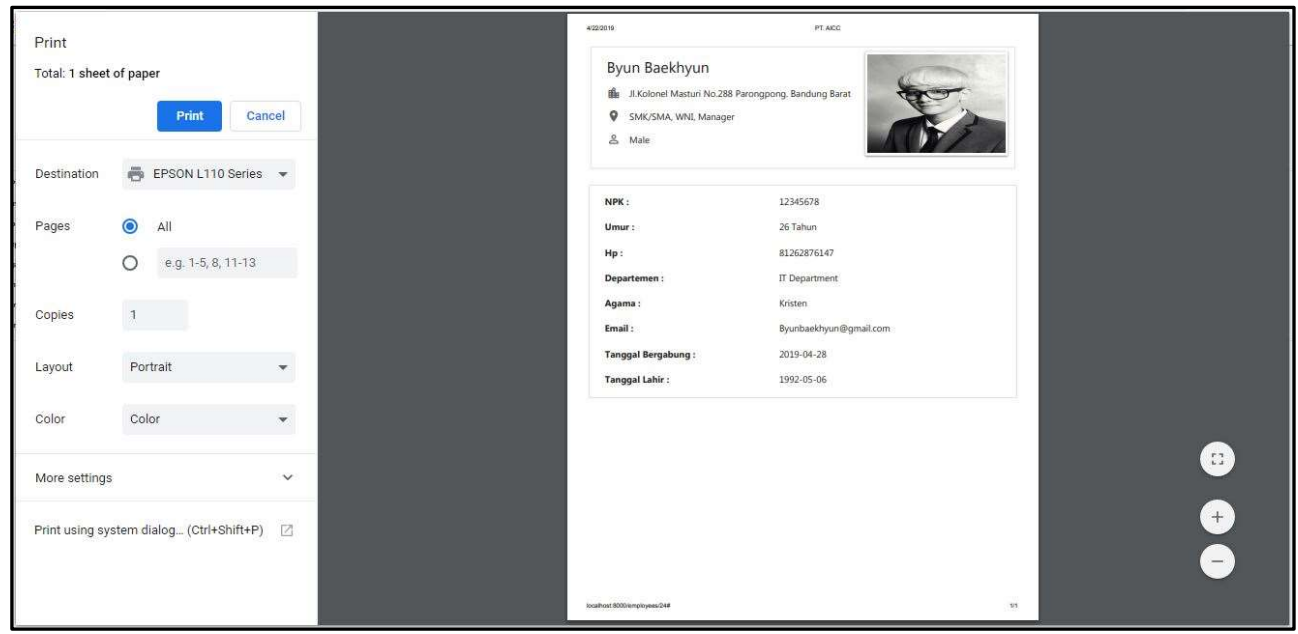

Gambar 13Tampilan print data karyawan

Pada Gambar 14 dan 15 ditampilkan hasil akhir dari halaman tambah data cuti dan laporan yang dapat langsung dicetak.

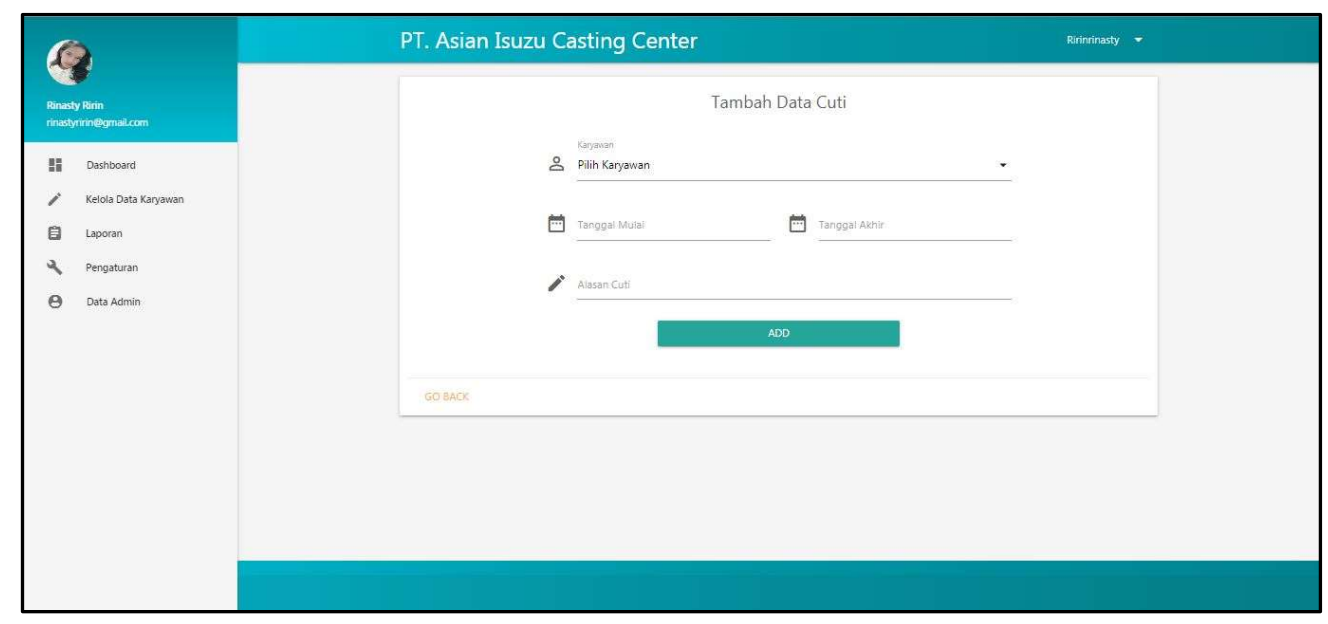

Gambar 14 Halaman tambah data cuti

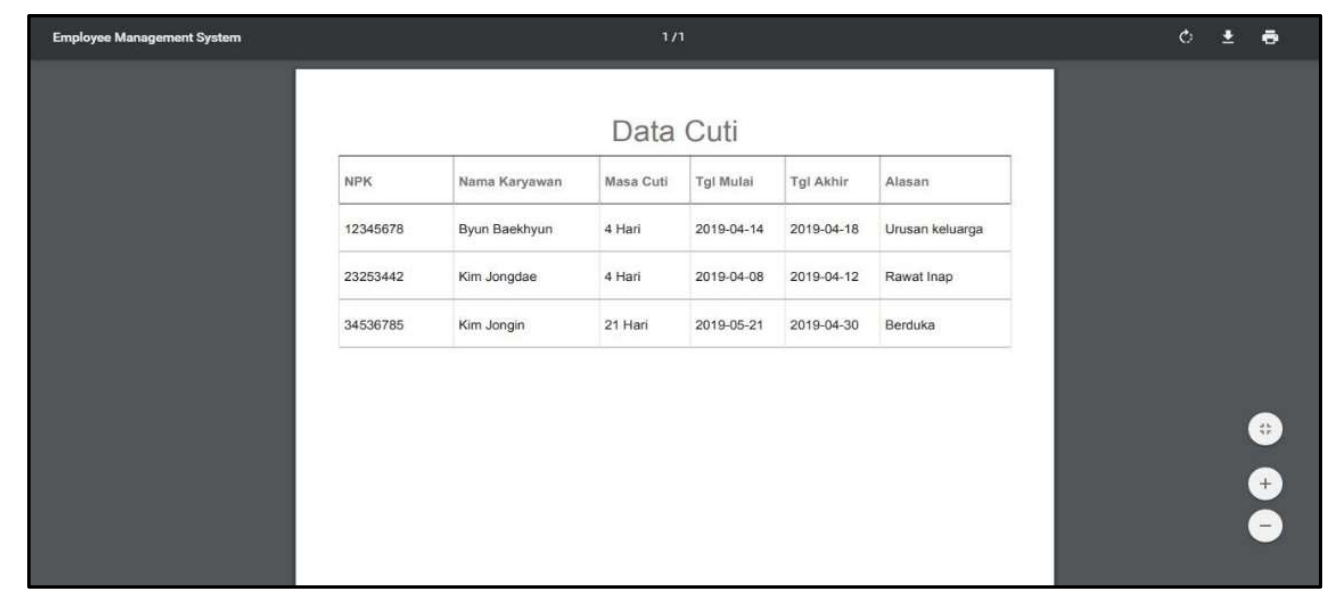

Gambar 15 Halaman print laporan data cuti 


\section{Pengujian Sistem}

Pada tahap pengujian ini penulis menggunakan metode Black Box. Pengujian Black box adalah pengujian terhadap suatu program untuk mengetahui program tersebut apakah berjalan dengan baik, baik dalam proses input maupun proses output dari program tersebut. Langkah-langkah pengujian terdapat di dalam Tabel 1 dan hasil pengujian dapat dilihat di Tabel 2. Hasil pengujian yang dilakukan mendapatkan hasil yang baik dan dapat diterima untuk setiap jenis uji. Dengan demikian aplikasi yang dikembangkan dapat digunakan sesuai dengan tujuan pembuatan aplikasi.

Tabel 1 Langkah-langkah Pengujian

\begin{tabular}{|c|c|c|c|}
\hline No. & Komponen sistem yang diuji & Butir uji & Jenis pengujian \\
\hline 1. & Login & Login & Black Box \\
\hline \multirow{4}{*}{2.} & \multirow{4}{*}{ Kelola Data Karyawan } & Tambah data Karyawan & \multirow{4}{*}{ Black Box } \\
\hline & & Edit data & \\
\hline & & Delete data & \\
\hline & & Cari data & \\
\hline \multirow{3}{*}{3.} & \multirow{3}{*}{ Laporan } & Edit data Karyawan & \multirow{3}{*}{ Black Box } \\
\hline & & Delete Data & \\
\hline & & Cari data Karyawan & \\
\hline \multirow{4}{*}{4.} & \multirow{4}{*}{ Pengaturan } & Tambah data Karyawan & \multirow{4}{*}{ Black Box } \\
\hline & & Edit data & \\
\hline & & Delete data & \\
\hline & & Cari data & \\
\hline \multirow{5}{*}{5.} & \multirow{5}{*}{ Admin } & Tambah data Karyawan & \multirow{5}{*}{ Black Box } \\
\hline & & Edit data & \\
\hline & & Delete data & \\
\hline & & Cari data & \\
\hline & & Cari data & \\
\hline
\end{tabular}

Tabel 2 Hasil Pengujian

\begin{tabular}{|c|c|c|c|c|}
\hline No. & Form yang diuji & Skenario uji & $\begin{array}{l}\text { Hasil pengujian } \\
\end{array}$ & Jenis Pengujian \\
\hline \multirow{2}{*}{1.} & \multirow{2}{*}{ Login } & $\begin{array}{l}\text { Masukkan data } \\
\text { username dan password } \\
\text { yang benar }\end{array}$ & $\begin{array}{l}\text { Proses login berhasil dan masuk } \\
\text { ke halaman dashboard }\end{array}$ & $\begin{array}{l}{[\sqrt{ }] \text { Diterima }} \\
{[\text { ] Ditolak }}\end{array}$ \\
\hline & & $\begin{array}{l}\text { Masukkan data } \\
\text { username dan password } \\
\text { yang salah }\end{array}$ & $\begin{array}{l}\text { Proses login gagal atau sistem } \\
\text { menolak }\end{array}$ & $\begin{array}{l}{[\sqrt{ }] \text { Diterima }} \\
{[\text { ] Ditolak }}\end{array}$ \\
\hline \multirow{5}{*}{2.} & \multirow{5}{*}{ Kelola Data } & $\begin{array}{l}\text { Tambah data barang } \\
\text { dengan dengan npk } \\
\text { berbeda, lalu klik } \\
\text { tambah }\end{array}$ & $\begin{array}{l}\text { Sistem sukses tambah data } \\
\text { karyawan ke dalam database }\end{array}$ & $\begin{array}{l}{[\sqrt{ }] \text { Diterima }} \\
{[\text { ] Ditolak }}\end{array}$ \\
\hline & & $\begin{array}{l}\text { Tambah data barang } \\
\text { dengan dengan npk } \\
\text { sama, lalu klik tambah }\end{array}$ & $\begin{array}{l}\text { Sistem menolak untuk data } \\
\text { karyawan }\end{array}$ & $\begin{array}{l}{[\sqrt{ }] \text { Diterima }} \\
{[\text { ] Ditolak }}\end{array}$ \\
\hline & & Edit data & $\begin{array}{l}\text { Mengubah data karyawan yang } \\
\text { sudah tersimpan di database }\end{array}$ & $\begin{array}{l}\text { [V] Diterima } \\
\text { [ ] Ditolak }\end{array}$ \\
\hline & & Delete data karyawan & $\begin{array}{l}\text { Menghapus data karyawan yang } \\
\text { sudah tersimpan di dalam } \\
\text { database }\end{array}$ & $\begin{array}{l}{[\sqrt{ }] \text { Diterima }} \\
{[\text { ] Ditolak }}\end{array}$ \\
\hline & & Cari data barang & $\begin{array}{l}\text { Sistem akan menampilkan data } \\
\text { yang dicari }\end{array}$ & $\begin{array}{l}\text { [V] Diterima } \\
\text { [ ] Ditolak }\end{array}$ \\
\hline 3. & Laporan & Edit data & $\begin{array}{l}\text { Mengubah data karyawan yang } \\
\text { sudah tersimpan di database }\end{array}$ & $\begin{array}{l}\text { [V] Diterima } \\
\text { [ ] Ditolak }\end{array}$ \\
\hline
\end{tabular}


Perancangan Aplikasi Manajemen Kepegawaian Berbasis Web Menggunakan Framework Laravel di Pt. Asian Isuzu Casting Center

\begin{tabular}{|c|c|c|c|c|}
\hline No. & Form yang diuji & Skenario uji & $\begin{array}{c}\text { Hasil pengujian } \\
\end{array}$ & Jenis Pengujian \\
\hline & & Delete data & $\begin{array}{l}\text { Menghapus data karyawan } \\
\text { yang sudah tersimpan di dalam } \\
\text { database }\end{array}$ & $\begin{array}{l}{[\sqrt{ }] \text { Diterima }} \\
{[\text { ] Ditolak }}\end{array}$ \\
\hline & & Cari data & $\begin{array}{lcc}\text { Sistem } & \text { menolak } & \text { untuk } \\
\text { menambahkan barang } & \\
\end{array}$ & $\begin{array}{l}\text { [V] Diterima } \\
{[\text { ] Ditolak }}\end{array}$ \\
\hline \multirow{4}{*}{4.} & \multirow{4}{*}{ Pengaturan } & $\begin{array}{l}\text { Tambah data baru ke } \\
\text { dalam database }\end{array}$ & $\begin{array}{l}\text { Memasukkan data baru pada } \\
\text { form yang telah disediakan dan } \\
\text { tekan tombol simpan untuk } \\
\text { menyimpan ke dalam database }\end{array}$ & $\begin{array}{l}{[\sqrt{ }] \text { Diterima }} \\
{[\text { ] Ditolak }}\end{array}$ \\
\hline & & Edit data & $\begin{array}{l}\text { mengubah data karyawan yang } \\
\text { sudah tersimpan di database }\end{array}$ & $\begin{array}{l}\text { [V] Diterima } \\
\text { [ ] Ditolak }\end{array}$ \\
\hline & & Delete data & $\begin{array}{l}\text { Menghapus data karyawan yang } \\
\text { sudah ada dalam database }\end{array}$ & $\begin{array}{l}\text { [V] Diterima } \\
\text { [ ] Ditolak }\end{array}$ \\
\hline & & Cari data & $\begin{array}{l}\text { Sistem akan menampilkan data } \\
\text { yang sudah dicari }\end{array}$ & $\begin{array}{l}{[\sqrt{ }] \text { Diterima }} \\
{[\text { ] Ditolak }}\end{array}$ \\
\hline \multirow{4}{*}{5.} & \multirow{4}{*}{ Admin } & $\begin{array}{l}\text { Tambah data baru ke } \\
\text { dalam database }\end{array}$ & $\begin{array}{l}\text { Memasukkan data baru pada } \\
\text { form yang telah disediakan dan } \\
\text { tekan tombol simpan untuk } \\
\text { menyimpan ke dalam database }\end{array}$ & $\begin{array}{l}{[\sqrt{ }] \text { Diterima }} \\
{[\text { ] Ditolak }}\end{array}$ \\
\hline & & Edit data & $\begin{array}{l}\text { mengubah data karyawan yang } \\
\text { sudah tersimpan di database }\end{array}$ & $\begin{array}{l}\text { [V] Diterima } \\
\text { [ ] Ditolak }\end{array}$ \\
\hline & & Delete data & $\begin{array}{l}\text { Menghapus data karyawan yang } \\
\text { sudah ada dalam database }\end{array}$ & $\begin{array}{l}\text { [V] Diterima } \\
\text { [ ] Ditolak }\end{array}$ \\
\hline & & Cari data & $\begin{array}{l}\text { Sistem akan menampilkan data } \\
\text { yang sudah dicari }\end{array}$ & $\begin{array}{l}\text { [V] Diterima } \\
\text { [ ] Ditolak }\end{array}$ \\
\hline
\end{tabular}

\section{Kesimpulan dan Saran}

Pada penelitian ini telah dilakukan perancangan aplikasi manajemen kepegawaian berbasis web menggunakan framework Laravel. Aplikasi dirancang untuk menggantikan sistem lama yang hanya menggunakan aplikasi Microsoft Excel dalam pengolahan data kepegawaian. Aplikasi yang dirancang menyediakan fitur login dengan hak akses yang berbeda-beda, memungkinkan penyimpanan dan pengelolaan data karyawan dalam pencatatan kontrak, cuti, izin dan resign. Aplikasi juga dirancang untuk menyediakan laporan yang dapat diakses dengan mudah oleh pengguna. Diharapkan nantinya aplikasi ini dapat diimplementasi untuk dapat digunakan di perusahaan. Adapun pengembangan selanjutnya dapat ditambahkan dengan fitur-fitur yang lain, seperti data keluarga, pengalaman pekerjaan dan data yang dibutuhkan agar dapat memberikan informasi statistik yang lebih baik. Kemudian dapat dikembangkan adannya akses khusus untuk karyawan sehingga semua data yang berhubungan dengan karyawan dapat diakses oleh karyawan yang bersangkutan.

\section{Daftar Pustaka}

[1] Jogiyanto, Analisis dan Desain Informasi Pendekatan terstruktur Teori dan Praktek Aplikasi, Yogyakarta, 2005.

[2] A. Kadir, Pengenalan Sistem Informasi, Yogyakarta: Andi, 2013.

[3] R. AS and M. Shalahudin, Rekayasan Perangkat Lunak: Terstruktur dan berorientasi objek, Bandung: Informatika, 2014.

[4] T. M. Connoly and C. E. Begg, Database Systems: A Practical Approach to Design, Implementation, and Management, Addison-Wesley, 2005. 
[5] R. C. Bororing, F. Tulusan and G. B. TAmpi, "Peran Sistem Informasi Manajemen Dalam Pengelolaan Administrasi Pegawai di Badan Kegawaian Daerah Provinsi Utara," Jurnal Administrasi Publik, vol. 1, no. 37, 2016.

[6] M. Rachmanaiah, H. A. Adrianto and A. Aziz, "Rancang Bangun Sistem Informasi Manajemen Kepegawaian dengan Metode the Open Group Architecture Framework (Toga F)," Jurnal Ilmu Pertanian Indonesia, vol. 16, no. 3, pp. 164-172, 2011.

[7] D. Abdullah, "Perancangan Sistem Informasi Pengolahan Data Pegawai Berbasis Web di Setdakab Aceh Utara," Jurnal Penelitian Teknik Informatika TECHSI, vol. 4, no. 1, pp. 35-45, 2014.

[8] H. Purwanto, "Perancangan Sistem Informasi Administrasi Kepegawian CV. XYZ Berbasis Web," Jurnal Sistem Informasi (JSI), vol. 5, no. 2, pp. 99-125, 2018. 